\title{
TRACING THE TRACE OF THOUGHT SHOLEH LAND AND ISLAMIC TRACTION IN SEMARANG
}

\author{
Muhammad Abdullah * \\ Indonesia Department, Faculty of Humanities, Diponegoro University, Semarang 50275, Indonesia.
}

\begin{abstract}
By translating many books of fiqh and Sufism into Javanese, $\mathrm{KH}$ Sholeh Darat has actually left a trail of brilliant Islamic thought in Semarang. This can be traced through his works which are works of translation, one of which is the magnum opus is the Book of Syarh Al Hikam. Therefore, the teachings of Islam are easily understood and accepted by the Semarang Islamic community. This is as conveyed in the message of preaching at the house of the Regent of Demak who is the uncle of R.A. Kartini. KH Sholeh Darat translated the Koran into Javanese using Arabic Pegon. Therefore, the effort to translate various books into Javanese is none other than the process of Islamization in Semarang, which is a trail of Islamic teaching that is very accommodating to Javanese culture in the Semarang area. Therefore, this manuscript needs to be studied philologically and thematically, especially the values of the propaganda of KH Sholeh Darat which provide a wind of harmony in religion. Through intertextual studies this study intends to find the character relationship of Syarah Al Hikam KH Soleh Darat. Through the learning of the Al Hikam book, traces of Islamic thought and the method of da'wah that combines Islamic culture and Javanese culture, accommodating, moderate, between the Shari'a and the tarekat is the harmonization of Islam can be accepted in the multicultural society in Semarang and Java in the 19th century.
\end{abstract}

\section{Introduction}

As recorded in history, that the success of Islamic da'wah (Islamization/preach) on Java didn't escaped the role of the ulamas, who's the noble works were able to transform Islamic values brilliantly. It was through this pesantren's work that the traditions of Islamic thought and intellectual are inherited from generation to generation, from one generation to the next. It was from this segment that the Indonesian intellectual network grows and develops. This was mainly happened in the era of the great ulama such as Sheikh Abdus Samad AlPalembani, Sheikh Abdur Rauf As-Singkili, Sheikh Yusuf Al-Makassari, Hamzah Fansuri, Syamsuddin As-Samatrani, Nuruddin Ar-Raniri, Muhammad Arsyad Al-Banjari, and others others until finally the generation of Imam Nawawi Al-Bantani, Kyai Ihsan Jampes, Kyai Saleh Darat [1], around 17-19 A.D. After the 19th century the names of the authors of the book appeared and pesantren literature, such as KH Mahfudz from Tremas who lived and taught in Mecca around the 1900s; another ulama was KH Ihsan bin Muhammad Dahlan

* Corresponding author: abdullahabah47@gmail.com 
from Jampes Kediri who wrote The Siraj Al-Thalibin book. Besides that, there was a very productive Javanese Ulama, KH Bisri Mustofa (father of KH Mustofa Bisri) from Rembang. He wrote more than twenty works of Islamic boarding schools. Other writers from Javanese Ulama were KH Muslikh from Mranggen (Muslikh Bin Abd Al-Rahman Al-Maraqi, 1981) who wrote various treatises about mystic path of the Qadiriyah wa Naqsabandiyah, and Ahmad 'Abdul hamid Al-Qandali from Kendal [3-7].

This Islamic intellectual tradition is revealed through written traditions in the form of education, thought and Islamic culture. That is why the traces of Islamic intellectual exactly appear in the form of classical religious scripts which contain various Islamic teachings, such as tauhid, tafsir, ahlak, fiqh, and sufism teaching, or also called pesantren literature [8]. However, it seemed that in Indonesia this literacy tradition actually declined after the triumph of the thinking of Imam Nawawi Al-Bantani from Banten whose works were widely used in the India region and Middle Eastern countries [9]. Among the factors that influenced the decline of the writing tradition of Indonesian ulama at that time until recently were (1) The increasing influence of the oral tradition that was institutionalized in the Islamic community tradition, so that the kyai or ulama preferred to actualize their knowledge through recitation and lectures; (2) The weak of literacy ethos in the pesantren tradition in Indonesia, especially due to the habit of conducting oral teaching, either in the form of religious lectures, or the delivery of yellow book teaching in Islamic boarding schools as manqul and sorogan, (3) and a shift in the orientation of society from the scientific world to another, such as the world of politics and economics [4, 7, 10, 11]

In its development, coastal literature is divided into written traditions and oral traditions. Among the written traditions in the pesantren literature include manuscripts about (1) syi'irs of pesantren, (2) Al-Barzanji poetry, (4) Burdah poetry (5) nadhoman, and others. Syi'ir of Islamic boarding schools is usually based on certain sources, for example, sourced from the Holy Qur'an, Al-Hadith, Burdah, Syaraful Anam, and others which are then mixed with the author's imagination. For example, Syi'ir of Abu Nawas which contains the prayer of Abu Nawas to Allah SWT to get His pleasure. The work of Syi'ir of Tomba Ati, Syi'ir Erang-erang Sekar Panjang by Kyai Siradj Payaman Magelang who tells about the state of hell torture and pleasure in heaven, and so on.

Although Javanese literary research has been carried out by many people, but it isn't the case with Syi'ir type literature. So far, the type of Syi'ir literature is less attractive to researchers. This is evident from various Javanese literary researchers conducted by experts such as Poerbatjaraka and Tardjan Hadidjaja (1952), Padmosoekotjo (1960), Ras (1985), Zoetmulder (1983), Subalidinata (1996), Nielsmulder (1986), [12-17] not talking about syi'ir literature. Strangely enough, in various Javanese manuscript catalogs such as the Pigeaud Catalog (1973), Girardet Catalog (1983), and the Behrend Catalog (1993) no records were found of syi'ir (Java: Singir). Academic research about syi'ir can still be counted on the fingers. The works are for example S-1 thesis [18], and an S-2 thesis [19].

The results of the inventory conducted by the Jakarta Central Museum about syi'ir literature only cover four syi'irs [20]. Yet, until now there seems to be no further research effort that holds a number of syi'ir manuscript among pesantren. Don't know exactly, why the research on syi'ir is still low in demand. Perhaps because of the general lack of socialization and publication of Syi'r works. To answer this problem, it is very important to edit and publish syi'ir scripts for the consumption of the academic community and society in general.

1. Borrow the term A.Teeuw (1994) in Indonesia: (Antara Kelisanan dan Keberaksaraan) Between Orality and Literacy. Jakarta: Gramedia. Literacy is intended as the ability to write texts scientifically [21]. 
2. Manqul's teaching system is a model of delivering education with a method of verbally decreasing texts, without the slightest change from the previous teacher (kyai) to the santri. While sorogan or talaqqi is a method of pesantren teaching by means of santri facing the kyai one by one (face to face) to receive oral teaching from the his/her kyai, according to the holy book he taught [10].

Today's discourse is increasingly being questioned is how far classical literary works including the literary works of Islamic boarding schools can provide the value of ethical teaching or use values and benefits for the readers. How far classical literature of Islamic boarding schools, both in the form of classical texts and syi'irs, have been able to provide an example of character education and a solution due to the widespread moral decadence of adolescents today. Its strategic value lies in how to ground the function of the character education in the learning process for students, maturing the younger generation of readers in the form of a more popular creative industry.

Considering the above reasons, this study seeks to explore, reveal the values of the past by revitalizing the potential of the literary work by digitizing and reactualizing the old script scriptorium. Thus, it can be seen how far the role of Islamic boarding school literature as a relic literature work from the past in coast culture can improve the quality of community empowerment. In other words, how can the potential of literature work and folklore be an alternative for the creation of a creative industry that is able to create new jobs, become a guide for the community, and a new mode for understanding various local wisdoms in the context of modernity. In addition, the potential of coastal literature work that is packed with the creative industry will be able to provide a special attraction for the development of the coastal tourism industry.

Islamic boarding schools as the basis of Islamic education, in addition to having a strong oral tradition, also have intellectual traditions revealed in various written works in the form of pesantren literary works, such as book literature or religious literature. According to Braginsky (1993: 3) [22] and Abdul Hadi WM (2004: 49) [23], religious literature is the books that contain the teachings of the formal laws of religion (shari'at), theology, Sufism and Islamic metaphysics. In the literature treasure of Islamic boarding schools, many religious scripts containing Islamic teachings have received less attention from researchers. Though the literature works of the pesantren according to experts have made a valuable contribution to the spread and development of Islam in the archipelago over a period of time. In fact, according to [24], the works of the pesantren determine the Islamic character of the Islamic kingdoms and the progress of Islam in Indonesia over the centuries.

In the history of Indonesian Islamic intellectuals, pesantren is the basis of traditional Islamic teaching rooted in classical Islamic books [11]. From the pesantren it can be known that the teaching system is based on written sources in the form of classic scripts and classic books published in the Middle East which are the work of salaf ulama. Namely the ulamas of fiqh, hadith, interpretations, theology and sufism that lived between the seventh century and the thirteenth century A.D. [10]. These types of books that in Malay literature and pesantren traditions are known as literary books $[8,25]$.

It's through this pesantren's work that the traditions of Islamic thought and intellectual are inherited from generation to generation, from one generation to the next. In this from of segment that the Indonesian intellectual intellectual network grows and develops. This was actually happened in the era of Sheikh Abdus Samad Al-Palembani, Sheikh Abdur Rauf AsSingkili, Sheikh Yusuf Al-Makassari, Hamzah Fansuri, Syamsuddin As-Samatrani, Nuruddin Ar-Raniri, to Imam Nawawi Al-Bantani, Kyai Ihsan Jampes, and Kyai Saleh AsSamarani. One of the works of Islamic intellectuals is the Kitab Syarah Al-Hikam. With this book, KH Saleh Darat is considered to have a very strong role in the process of da'wah and Islamization in Java. Why is that, because this Javanese-based book teaching model is able 
to attract people to be easily attracted to Islam. This cultural approach has also been used as a branding of the nine saints (Java: Wali Songo) preaching in their time. That is to teach Islam through an accommodating and eclectic approach to Javanese culture.

Based on the background above, this research problem can be formulated as follows. Considering the importance of the text of KH Soleh Darat's Kitab Syarah Al Hikam in Central Java which uses Javanese language and contains the values of Shari'a and tarekat, is a representation of harmonization of Islam in Java, it is important that the religious text be preserved, by transliteration, reconstruction, and text edits; Concrete steps to maintain the existence of the Syarah Al Hikam text is carried out by making a description of the text, transliteration, and translation of the text. The second is done by analyzing the contents of the text by approaching content analysis. To realize the two steps to save the text, it's necessary to carry out research in the field, how the function of the text of the Syarah Al Hikam is in Islamic society on Java, especially in Semarang and its surroundings.

This research was conducted with the aim of saving and preserving Islamic intellectual heritage in coastal community, especially as a moderate model of da'wah, by transliterating and traslation of the text of the Book of Syarah Al Hikam. The second specific purpose is to make the description, transliteration, and translation of the Al Hikam text so that it can be read and enjoyed by lay readers in studying the religion of Islam. The third purpose is to reveal and analyze the contents of the text of the Book of Syarah Al Hikam, so that the meaning and function of the text of the book is known in society.

\section{Discussion and Result}

Figures and tables, one of the cultural heritages works of the coastal community is the pesantren's literary work. The meaning of pesantren literary term is a collection of literary works (religious literature) oral literary works, and syi'ir literature which were born and developed in the pesantren environment, either problems concerning dogmatic-ritual teachings or rational-spiritual teachings. Among the literary characteristics of the pesantren are (1) pesantren literature usually speaks Arabic and has Arabic inscriptions, (2) sometimes the Islamic boarding school's literature speaks a new Javanese with Arabic-Pegon writing, (3) born and developed in the early 19th century, and developed rapidly around the 19th century until the 20th century, (4) pesantren literature in the form of oral traditions and writing traditions, which contained moral teachings, fiqh, tauhid, sufism, theology, and works of syi 'ir, nasyid and others, (5) usually pesantren literature is read in scientific halaqah, certain ritual ceremonies and sometimes showed as performing arts, and (6) pesantren literature is also more or less affected by Middle Eastern literature, Arabic literature or Parsi literature $[7,26,27]$.

It's through this pesantren's work that the traditions of Islamic thought and intellectual are inherited from generation to generation, from one generation to the next. In this from of segment that the Indonesian intellectual intellectual network grows and develops. This was actually happened in the era of the great ulama such as Sheikh Abdus Samad Al-Palembani, Sheikh Abdur Rauf As-Singkili, Sheikh Yusuf Al-Makassari, Hamzah Fansuri, Syamsuddin As-Samatrani, Nuruddin Ar-Raniri, Muhammad Arsyad Al-Banjari, and others others until finally the generation of Imam Nawawi Al-Bantani, Kyai Ihsan Jampes, Kyai Saleh Darat , around 17-19 A.D. After the 19th century the names of the authors of the book appeared and pesantren literature, such as KH Mahfudz from Tremas who lived and taught in Mecca around the 1900s; Another cleric was KH Ihsan bin Muhammad Dahlan from Jampes Kediri who wrote the Siraj Al-Thalibin book. Besides that, there was a very productive Javanese Ulama, KH Bisri Mustofa (father of KH Mustofa Bisri) from Rembang. He wrote more than twenty of Islamic boarding schools' literature. Other writers from Javanese scholars are KH 
Muslikh from Mranggen [2] who wrote various treatises on the Qadiriyah waNaqsabandiyah order, and Ahmad 'Abdul hamid Al-Qandali from Kendal [3-5], [28-30].

This Islamic intellectual tradition is revealed through written traditions in the form of education, thought and Islamic culture. That is why the traces of Islamic intellectuals actually appear in the form of classical religious scripts which contain various Islamic teachings, such as tauhid, tafsir, ahlak, fiqh, and sufism teaching, or also called pesantren literature [8]. However, it seemed that in Indonesia this literacy tradition actually declined after the triumph of the thinking of Imam Nawawi Al-Bantani from Banten whose works were widely used in the India region and Middle Eastern countries[9]. Among the factors that influenced the decline of the writing tradition of Indonesian ulama at that time until recently were (1) The increasing influence of the oral tradition that was institutionalized in the Islamic community tradition, so that the kyai or ulama preferred to actualize their knowledge through recitation and lectures; (2) The weak of literacy ethos in the pesantren tradition in Indonesia, especially due to the habit of conducting oral teaching, either in the form of religious lectures, or the delivery of yellow book teaching in Islamic boarding schools as manqul and sorogan, (3) and a shift in the orientation of society from the scientific world to another, such as the world of politics and economics $[4,10,11,28]$.

In its development, coastal literature is divided into written traditions and oral traditions. Among the written traditions in the pesantren literature include manuscripts about (1) syi'irs of pesantren, (2) Al-Barzanji poetry, (4) Burdah poetry (5) nadhoman, and others. Syi'ir of Islamic boarding schools is usually based on certain sources, for example, sourced from the Holy Qur'an, Al-Hadith, Burdah, Syaraful Anam, and others which are then mixed with the author's imagination. For example, Syi'ir of Abu Nawas which contains the prayer of Abu Nawas to Allah SWT to get His pleasure. The work of Syi'ir of Tomba Ati, Syi'ir Erangerang Sekar Panjang by Kyai Siradj Payaman Magelang who tells about the state of hell torture and pleasure in heaven, and so on.

Although Javanese literary research has been carried out by many people, but it isn't the case with Syi'ir type literature. So far, the type of Syi'ir literature is less attractive to researchers. This is evident from various Javanese literary researchers conducted by experts such as Poerbatjaraka and Tardjan Hadidjaja (1952), Padmosoekotjo (1960), Ras (1985), Zoetmulder (1983), Subalidinata (1996), Nielsmulder (1986) [12-17], not talking about syi'ir literature. Strangely enough, in various Javanese manuscript catalogs such as the Pigeaud Catalog (1973), Girardet Catalog (1983), and the Behrend Catalog (1993) no records were found of syi'ir (Java: Singir). Academic research about syi'ir can still be counted on the fingers. The works are for example S-1 thesis (Muayyanah, 1996; Saifuddin, 1997), and an S-2 thesis (Muzakka, 1999).

1. Borrow the term A.Teeuw (1994) in Indonesia: (Antara Kelisanan dan Keberaksaraan) Between Orality and Literacy. Jakarta: Gramedia. Literacy is intended as the ability to write texts scientifically.

2. Manqul's teaching system is a model of delivering education with a method of verbally decreasing texts, without the slightest change from the previous teacher (kyai) to the santri. While sorogan or talaqqi is a method of pesantren teaching by means of santri facing the kyai one by one (face to face) to receive oral teaching from the his/her kyai, according to the holy book he taught (Dhofier, 1982: 12).

The results of the inventory conducted by the Jakarta Central Museum about syi'ir literature only cover four syi'irs (Soewignjo and Wirawangsa, 1920: 318). Yet, until now there seems to be no further research effort that holds a number of syi'ir manuscript among pesantren. Don't know exactly, why the research on syi'ir is still low in demand. Perhaps because of the general lack of socialization and publication of Syi'r works. To answer this problem, it is very important to edit and publish syi'ir scripts for the consumption of the academic community and society in general. 
Today's discourse is increasingly being questioned is how far classical literary works including the literary works of Islamic boarding schools can provide the value of ethical teaching or use values and benefits for the readers. How far classical literature of Islamic boarding schools, both in the form of classical texts and syi'irs, have been able to provide an example of character education and a solution due to the widespread moral decadence of adolescents today. Its strategic value lies in how to ground the function of the character education in the learning process for students, maturing the younger generation of readers in the form of a more popular creative industry.

Considering the above reasons, this study seeks to explore, reveal the values of the past by revitalizing the potential of the literary work by digitizing and reactualizing the old script scriptorium. Thus, it can be seen how far the role of Islamic boarding school literature as a relic literature work from the past in coast culture can improve the quality of community empowerment. In other words, how can the potential of literature work and folklore be an alternative for the creation of a creative industry that is able to create new jobs, become a guide for the community, and a new mode for understanding various local wisdoms in the context of modernity. In addition, the potential of coastal literature work that is packed with the creative industry will be able to provide a special attraction for the development of the coastal tourism industry.

Islamic boarding schools as the basis of Islamic education, in addition to having a strong oral tradition, also have intellectual traditions revealed in various written works in the form of pesantren literary works, such as book literature or religious literature. According to Braginsky (1993: 3) [22] and Abdul Hadi WM (2004: 49) [23], religious literature is the books that contain the teachings of the formal laws of religion (shari'at), theology, Sufism and Islamic metaphysics. In the literature treasure of Islamic boarding schools, many religious scripts containing Islamic teachings have received less attention from researchers. Though the literature works of the pesantren according to experts have made a valuable contribution to the spread and development of Islam in the archipelago over a period of time. In fact, according to Soebardi (1976: 3) [24], the works of the pesantren determine the Islamic character of the Islamic kingdoms and the progress of Islam in Indonesia over the centuries.

In the history of Indonesian Islamic intellectuals, pesantren is the basis of traditional Islamic teaching rooted in classical Islamic books [11]. From the pesantren it can be known that the teaching system is based on written sources in the form of classic scripts and classic books published in the Middle East which are the work of salaf ulama. Namely the ulamas of fiqh, hadith, interpretations, theology and sufism that lived between the seventh century and the thirteenth century A.D. [10]. These types of books that in Malay literature and pesantren traditions are known as literary books Wahid, 1989: 31; Liaw Yock Fang, 1993: 41) $[8,25]$.

Down below is the text of Syarah Al Hikam by KH Saleh Darat :

Mangka anuturaken Syekh Ibnu 'Athā'illah waliyullah/ ing alamate wang kang kekanda lan marang liyane Allah kèlawan/ wani pangandikane syaeh iku (min 'alāmati al-i'timādi 'ala al-'amali nuqshanul ar-rijāi 'inda wujudi az-zalali) tègèse setengah saking/ alamate wang kang cecekalan ingatase amale iku kurang/ pangarèp are ping rahmate Allah nalikane tumiba ing dalèm/ kaluputan, kaya ma'siate utawa lali marang Allah,/ kaya lamun ngucap atine ba'dane tumiba marang keluputan:/ “uga ingsun wes mesti manjing neraka sebabl iki ma'siat, lan Allah wes ora ngapura marang ingsun”. Balik wajib marang kang tumiba marang kaluputan arèp ndependepel marang Allah ta'ala, lan rumangsaha sira satuhune tumibanel marang keluputanne iku kèlawan sifat qahare Allah. // 
Meaning:

Therefore, Sheikh Ibn Atha'illah mentions the signs of people who rely on other than Allah SWT through his following words: min 'alāmati ali'timādi' ala al-'amali nuqshanu ar-rijāi 'inda wujudi az- zalali means : Among the signs that a person is leaning on the strength of the charity of his endeavor is a lack of hope for the grace of God's gift when it happens to a mistake or sin. For example, immoral or forgetful of remembering Allah SWT, that is when someone's heart says after making a mistake, "I will definitely go to hell because of my sin, and Allah will not forgive my sin". However, people should fall in a sin must bring themselves closer to Allah. and feel that he committed sin because of the nature of Qahhar (The Mighty) Allah SWT.

By translating texts from Arabic into Javanese, such as the Al Hikam Syarh Book, Kyai Shaleh wants to invite and guide Javanese Muslims, who in fact are unfamiliar with Arabic in order to understand Shari'a, understand the teachings of Islam, and understand the wisdom of Islam. Thus, the ethos of the da'wah of Kyai Saleh was a new breakthrough at that time in the methods and Islamization of the 18th century. Besides translating the book of Al Hikam, Kyai Shaleh also translated other books, such as Munjiyat, Tafsir Quran, Majmu 'Syarif, etc.

KH Shole Darat included Indonesian ulama who were productive in writing books. Quite a lot of the books by KH Sholeh Darat, there are about 14 books, most of which are translation works Majmu'at Asy-Syari'at al Kifayat lil awam, Munjiyat, Methik Saking Ihya 'Ulumuddin al; Ghazali, Syarah Al-Hikam (summary of Ibn Athoillah work), Lathaif alThoharoh, Manasik Al Hajj, Tarjamah Sabilul 'ala Jauharah al-Tauhid, Faidlurrahman, dll.

On that occasion, KH Soleh Darat had the opportunity to study religion with his father's friends. Among them are Kyai Hasan Besari, Kyai Syada (Diponegoro's warrior), Kyai Darda, Kyai Murtadho, and Kyai Jamsari (Founder of the Kjamsaren Solo Islamic Boarding School). Kyai Hasan Besari is the aide of Prince Diponegoro. One of his grandchildren, that is KH M. Moenawir, founder of the Krapyak Jogjakarta Islamic Boarding School, was a student of KH Sholeh Darat. In fact, KH Sholeh also learned from KH Asy'ari (Kyai Guru) from Kaliwungu, Kendal. From the Haramain area, he studied with the following teachers, Syeh Muhammad Al Maqri al Mashri al Makki, Syeh Muhammad bin Sulaiman Hasballah, Sayyid Ahmad Bin Zaeni Dahlan, Syeh Muhammad Shalih Az-Zawawi al Makki, etc.

His struggle in the field of Islamic sciences, KH Sholeh Darat has received valuable input from RA Kartini, especially in relation to the learning methodology of Arabic books into Javanese (pegon letters). Kartini when participating in the reading of KH Sholeh Darat at the residence of the Regent of Demak, encouraged her to suggest that the Al Quran book be translated in Javanese, so that it was easily understood by ordinary people. Because at that time there were many Arabic terms that were not widely understood by ordinary Javanese, so many experienced symptoms of language called paracustie. Even the aqeedah teachings of Kanjeng Sunan Kalijaga undergo a paracustie process, that is the song Sluku-Sluku Bathok.

The Sentence Opener in the Faidlurrahman Book, KH Sholeh was published as follows:

"Sebab kerono gegawe wasilah marang barang kang luweh gede iyo iku weruhe wong akih marang ilmu lan hikmah lan asrar. Ing hale asrar iku asrare Ratu kang agung lan maneh iki ta'jil iku ta'jil ata wal hikam”.

The opening of this sentence becomes a textual fact from KH Sholeh Darat towards RA Kartini's anxiety in terms of opposing the secrets of the Qur'an. Kyai Sholeh Darat submits a request to publish part of the interpretation at the request of some of the friends (ikhwan kito fiddin). Islamic Da'wah (preach) certainly requires material and language that is contextual. That is to provide material and methods of Islamic propaganda that pay attention to and target the era. KH Sholeh Darat was quite intelligent and responsive to the situation of the people 
of Isklam Java. Most people do not understand Arabic, as a source and reference for studies and Islamic da'wah.

Therefore, in the process of the 19th century Islamization of Java, KH Sholeh Darat used adaptive cultural attitudes. It's the model of the learning approach in Javanese, so that it's understood by ordinary people. This approach was carried out by KH Sholeh Darat by translating lots of yellow books into Javanese. This was also done by KH Bisri Mustofa (Gus Mus's father) by compiling the Qur'anic commentary, Al-Ibris. KH Sholeh Darat is a Sufu scholar who is strong in deepening Sufistic values. Sufism study ethos is very clear from strong sources, Ihya ulumuddin, Minhajul abidin, Al-Hikam etc.

In the context of the present era, as it is now, when hedonism, matetialism, syncretism, hybridity, and liberalism are very lively in our lives, esoteric nuances are urgently needed. KH Sholeh is very concerned about studies that bring pilgrims to taqorrub ilallah, making the orientation of the living only to Allah. Using modern language, oriented to the monotheistic paradigm. It was also done by many great ulamas, such as Imam Al Ghozali, Sheikh Ab dul Qadir Al Jailani, Syeh Samman, Imam Nawawi Al Bantani, etc. KH Sholeh Darat with his father, KH Umar (who died and was buried in Makkah) became a friend of Pangeran Diponegoro's trust to guard and coordinate fighters in the jihad fii sabilillah movement for the northern part of Java against Dutch colonialism.

On that occasion, KH Soleh Darat had the opportunity to study religion with his father's friends. Among them are Kyai Hasan Besari, Kyai Syada (Diponegoro's warrior), Kyai Darda, Kyai Murtadho, and Kyai Jamsari (Founder of the Kjamsaren Solo Islamic Boarding School). Kyai Hasan Besari is the aide of Prince Diponegoro. One of his grandchildren, that is KH M. Moenawir, founder of the Krapyak Jogjakarta Islamic Boarding School, was a student of KH Sholeh Darat.

KH Sholeh Darat's principle of moderation is very apparent in the following points. First, KH Sholeh Darat in his study tried to synthesize between the tendencies of Shari'a teachings and the teachings of the principles. It is this balance that is able to bridge the mystical and kejawen teachings in Java at that time. Secondly, KH Sholeh Darat was also able to synthesize Salaf Islamic teachings with a Javanese cultural context which at that time had many nuances of senkretisme. This is really a beautiful Isamization approach. Third, the nuances of Islamic moderation in the da'wah(preach) ethos of KH Sholeh seemed to meet with wasyathiyah Islam which had also been exemplified in Islamic history. As exemplified by the Prophet SAW and his companions, and Islamic ulamas of the past.

Captions should be typed in 9-point Times. They should be centred above the tables and flush left beneath the figures.

\section{Conclusions}

From the above description can be drawn as follows:

a. The figure of KH Soleh Darat is a well-known figure of Javanese ulama who is able to embody Islamic da'wah with an accommodating and persuasive language.

b. Javanese Islamization by KH Soleh Darat through the translation of Arabic books into Javanese was a concrete form of simplification of the method of preaching (da'wah) on Java which respected Javanese tradition and language as the regional language of coastal Javanese.

c. The KH Soleh Darat Islamization model with its translation and learning through Kitab Al Hikam is truly a way of Islamic education that succeeded in bringing Javanese Islamic society to develop Islam. 


\section{References}

[1] S. bin U. Al-Samarani, "Penafsiran Shalih bin Umar Al-Samarani," (1903)

[2] M. bin A. A.-R. Al-Maraqi, Penafsiran Muslikh bin Abd Al-Rahman Al-Maraqi. (1981)

[3] A. Azra, Jaringan Ulama Timur Tengah dan Kepulauan Nusantara. (1994)

[4] M. van Bruinessen, Kitab Kuning: Pesantren dan Tarekat. (1999)

[5] A. Daudy, Syeh Nuruddin Ar-Raniri. (1978)

[6] B. Baried, Kedatangan Islam dan Penyebarannya di Indonesia, Suatu Kajian Lewat Naskah Melayu. (1997)

[7] M. Thohir, Inventarisasi Karya-karya Sastra Pesantren di Kaliwungu Kendal. (1997)

[8] L. Yock Fang, "Sejarah Kesusastraan Melayu Klasik," Jakarta: Erlangga, (1993)

[9] Hasan and A. Rifai, Warisan Intelektual Islam Indonesia. (1990)

[10] Z. Dhofier, Tradisi Pesantren. (1982)

[11] Abdullah, Masalah Ilmu Sejarah dan Pengajaran Sejarah Yang. Reflektif dan Inspiratif. Pengajaran Sejarah. (1995)

[12] T. Hadidjaja, Kepustakaan Djawa. (1952)

[13] S. Padmosoekotjo, Ngéngréngan kasusastran Djawa: kanggo para siswa sekolah guru lan sekolah landjutan lijané. (1960)

[14] Ras, Bunga Rampai Sastra Jawa Mutakhir. Jakarta: Grafiti Press., (1985)

[15] Zoetmulder, Kalangwan. (1983)

[16] R. Subalidinata, Kawruh Kasusastraan Jawa. Yogyakarta: Yayasan Pustaka Nusatama, (1996)

[17] N. Mulder, Kepribadian Jawa dan pembangunan nasional. Gadjah Mada University Press, (1986)

[18] Saifuddin, Metode Penelitian. (1997)

[19] M. Muzzaka, Tanwiru'L-qari'sebagai penyambut teks tajwid Tuchfatu'L-athfal. (1999)

[20] Soewignjo and Wirawangsa, Pratélan Kawontenaning. (1920)

[21] A. Teeuw, Indonesia anatara kelisanan dan keberaksaraan. Jakarta: Pustaka Jaya, (1994)

[22] V. I. Braginsky, Tasawuf dan sastera Melayu : kajian dan teks-teks. Jakarta : RUL, (1993)

[23] Abdul H. WM, Hermeneutika, Estetika, dan Religiusitas. (2004)

[24] Soebardi, The Palace of Islam. (1976)

[25] A. Wahid, Pribumisasi Islam. Jakarta: Islam Indonesia Menatap Masa Depan, Perhimpunan Pengembangan Pesantren dan Masyarakat (P3M), (1989)

[26] Sulistyo Basuki, Pengantar dokumentasi ilmiah. (1989)

[27] M. A. Abdullah, Studi agama: normativitas atau historisitas? Pustaka Pelajar, (1996)

[28] H. Thohari, Melacak Jejak langkah Intelektual Islam Indonesia. Suara Merdeka, (1990)

[29] G. W. J. Drewes, Kisah-kisah ajaib Syekh Abdulkadir Jailani. Jakarta : Pustaka Jaya, (1990)

[30] Y. T. Sumaningsih, "Sistem Visual Kawasan Pusat Kota Lama, studi kasus: Pusat Kota Lama Semarang." Thes. Mag. Arch., Universitas Gadjahmada Yogyakarta, (1995) 